\title{
Corrigendum
}

\section{Corrigendum to "Modeling and Analysis of Photo-Voltaic Solar Panel under Constant Electric Load"}

\author{
Elias M. Salilih ${ }^{1 D},{ }^{1}$ Fiker A. Haile, ${ }^{2}$ and Yilma T. Birhane ${ }^{2}$ \\ ${ }^{1}$ Department of Mechanical Engineering, Jigjiga University, P.O. Box 1020, Jigjiga, Ethiopia \\ ${ }^{2}$ School of Mechanical \& Industrial Engineering, A. A Institute of Technology-AAU, Addis Ababa, Ethiopia \\ Correspondence should be addressed to Elias M. Salilih; elju99@gmail.com
}

Received 11 August 2020; Accepted 11 August 2020; Published 12 September 2020

Copyright ( $(2020$ Elias M. Salilih et al. This is an open access article distributed under the Creative Commons Attribution License, which permits unrestricted use, distribution, and reproduction in any medium, provided the original work is properly cited.

In the article titled "Modeling and Analysis of PhotoVoltaic Solar Panel under Constant Electric Load" [1], Dr. Fiker Ayalew Haile was missing from the author list. Dr. Haile has contributed to the study by obtaining, analyzing, and interpreting data. The corrected author list is shown above.

\section{Conflicts of Interest}

The authors declare that they have no conflicts of interest.

\section{References}

[1] E. M. Salilih, F. A. Haile, and Y. T. Birhane, "Modeling and Analysis of photo-voltaic solar panel under constant electric Load," Journal of Renewable Energy, vol. 2019, Article ID 9639480, 10 pages, 2019. 